\title{
Inter-Sectoral Cooperation for the Implementation of Social Policy in Rural Areas. Proposal of Research Tool*
}

\begin{abstract}
The cooperation of local public institutions with non-governmental organisations and citizens can increase chances for the effective implementation of social policy, understood as a set of activities on behalf of satisfying social needs and resolving social issues. The aim of this article is to present a tool that would enable us to determine the level of cooperation between entities in the scope of co-creation and co-production of social services that satisfy the needs of residents of rural municipalities (gmina). The article contains an overview of analyses conducted in 2018 on a sample of public institutions responsible for satisfying social needs and resolving social issues representative of rural municipalities. In light of these analyses the scale is a three-factor construct and includes the following factors: 1 . Seeking entities for cooperation and cooperating with them, 2 . Including residents of municipalities in undertakings on their own behalf, 3. Evaluation of cooperation and working towards future cooperation.
\end{abstract}

Keywords: local social policy, cooperation between entities involved in local social policy, rural municipality (gmina).

\section{Introduction}

Contemporary social policy is attributed characteristics such as multisectorality, activeness and pluralism (Grewiński, Karwacki and Rymsza 2010; Necel and Nosal 2016). Entities responsible for its implementation at a local level, i.e. entities which

Katarzyna Zajda, PhD, Faculty of Economics and Sociology, University of Łódź, 3/5 POW Street, 90-255 Łódz, katarzyna.zajda@uni.lodz.pl; Sławomir Pasikowski, PhD, Faculty of Educational Sciences, University of Łódź, 3/5 POW Street, 90-255 Łódz, slawomir.pasikowski@uni.lodz.pl.

* The article was prepared within the framework of the project "Local systems of social innovations in rural areas" funded by the Polish National Science Centre, Research Project Reference No.: 015/19/D/ HS6/00690, DEC-2015/19/D/HS6/00690, Contract No. UMO-2015/19/D/HS6/00690. 
participate in satisfying social needs and resolving local social issues, include not only public institutions, but also non-governmental organisations and informal groups of residents (Leś 2013).

According to the contemporary model of social policy and the requirements of new public governance concept, public institutions should no longer be solely responsible for its implementation or for commissioning local entities to perform selected tasks. Such institutions should manage the process of satisfying the social needs of citizens, in cooperation with other local entities - both formal (NGOs) and informal (residents of territorial entities).

The advantages of public actors' cooperation with the social and economic sector have been underlined in the Strategy for Responsible Development by 2020, adopted by the Council of Ministers on 14 February 2017 (MIiR 2017). It is the main Polish development strategy defining the main conditions, objectives and directions of the country's development in social, economic, regional and spatial dimensions.

In the light of its objectives, regional policy should be focused on problem areas. In rural development it is very important to activate areas threatened by marginalisation (MIiR 2017, p. 13). Local governments have a greater role to play in solving local problems. They should be responsible for the development of inter-sectoral partnerships, because inter-sectoral cooperation can create social capital, the sense of responsibility of key stakeholders (local governments, business, residents, non-governmental organisations) for the development of their area (MIiR 2017, p. 8-14). The strategy indicates that "Different actors become not only contributors to development activities, but also co-create them, which involves building a sense of co-responsibility for the process of development" (MIiR 2017, p. 40).

However, cooperation requires many changes in the functioning of public institutions, including abandoning the perception of other local entities only as cheaper contractors (compared with public institutions) who perform commissioned tasks, and including local residents in the process of satisfying their social needs and resolving their problems - a difficult task in the post-socialist reality of Poland.

The aim of this article is to present a tool that would enable us to determine the level of formal and informal cooperation between public institutions from rural municipalities, their residents and local NGOs in the scope of co-creation and co-production of social services. ${ }^{1}$ The article will present the results of analyses

1 Social services are a form of service provided by the state, local governments or non-public entities, the aim of which is to satisfy social needs. These include services such as social welfare, healthcare, culture, education or public safety (Zacharko 2017, p. 768). 
conducted in 2018 on a sample of public institutions responsible for implementing social policy at a local level representative of rural municipalities in Poland.

\section{Relations Between Local Entities Responsible for Implementing Social Policy in Rural Areas}

The assumptions of the contemporary model of social policy correspond with those of the new public governance concept (Dean 2018, p. 181; Radnor and Osborne 2013). In this light (it should again be emphasised) non-governmental organisations and citizens are not only the beneficiaries but also co-creators of social services provided by public institutions ${ }^{2}$ (Pestoff 2012; Pestoff, Brandsen and Verschuere 2012). Thus they become entities cooperating with public institutions in implementing local social policy, not only in the scope of providing public services, but also creating them ${ }^{3}$ (which distinguishes their role from the one outlined in the new public management concept, see: McLaughlin, Ferlie and Osborne 2001).

Cooperation can be graduated. It is preceded by entities mutually informing themselves about their actions. The unconditional recognition of public consultation as its form is problematic. A review of source literature reveals that in general local governments in Poland are rather sceptical of public consultations, which can be carried out pursuant to point 1 of Article 5a of the Local Government Act of 8 March 1990. They only use this instrument of dialogue with residents when they are obliged to do so. ${ }^{4}$ Optional public consultations, which can be organised to discuss any matter that is of importance to the residents of a given locality, are seldom carried out. Moreover, as indicated by Jarosław and Natalia Świdyńscy: The main mistake during the organisation of public consultations lies in carrying them

2 This assumption accompanies other similar concepts, i.e. good governance, public governance and co-production (Sześciło 2015, p. 18)

3 This cooperation is an example of innovation in governance, understood as social practices of management of the process of implementing social policy at a local level, hitherto absent in a given local context (Hartley 2005, p. 28). These practices may contribute to the emergence of long-lasting change in the system of governance, in accordance with the "cracks and fissures" principle (Richardson, Durose and Perry 2018, p. 146).

4 In rural municipalities there are obligatory public consultations in such situations as: creating, merging, dividing, dissolving municipalities and establishing their borders; awarding city status to a municipality or town and establishing its borders; establishing and changing the names of municipalities and the seat of their authorities; before a resolution to create an auxiliary municipal entity, initiated by an entity other than local residents; before a resolution on the statute of an auxiliary municipal entity; before a motion to establish an additional name of a locality in the language of a national or ethnic minority; before the procedure of establishing, changing and repealing legal names of localities and their parts, as well as physiographic objects. 
out in a narrow and closed circle of experts, and in order to gain public approval for a decision that has already been made (2016, p. 250). Local rural governments are no exception. Local authorities in rural municipalities are reluctant to carry out public consultations, especially if the participants include residents who are experiencing social problems. They are afraid of their entitledness, lack of confidence in officials, the emergence of new social conflicts or the extension of the decision-making process (Marchaj 2016, p. 62). Lack of citizen participation in decision-making concerning any areas of local development tends (paradoxically) to be an indication of positive social attitudes (Zajda 2018). Public consultations are therefore not always a form of cooperation between local governments, and non-governmental organisations and residents.

Regulations included in the Local Government Act do not exhaust the possibilities of cooperation between local governments, and non-governmental organisations and residents themselves. This issue is regulated for instance by the Act of Public Benefit Activity and Volunteerism of 24 April 2003. It determines the regulations regarding public benefit activity by non-governmental organisations and the use of this activity by public administration in order to perform public tasks. These include social security, preventing social exclusion, professional integration and reintegration of people at risk of social exclusion, as well as education. According to this act a local government can commission a nongovernmental organisation (by subsidising it) to perform public tasks or support the organisation in the realisation of a public task by financing its execution (Sidor 2017 , p. 600). Both forms of action create opportunities for cooperation.

In the post-socialist reality of Poland, which is characterised by low level of social capital (Karolewski 2016), cooperation consisting in co-creation and particularly formal co-production of social services is still difficult to achieve (Zajda and Pasikowski 2018). However, over the years we have observed a process of learning this cooperation, as part of local partnerships such as local action groups including representatives of local authorities, non-governmental organisations and entrepreneurs (Furmankiewicz and Macken-Walsh 2016; Halamska and Maurel 2010; Halamska, Śpiewak and Michalska 2010; Pawłowska, Gąsior-Niemiec and Kołomycew 2014). Nevertheless, as the LEADER approach indicates, rural NGOs often remain in a relationship based on patronage rather than partnership with local authorities. Often does not mean always. The rural NGO sector is diverse. Moreover, as noted by Jan Herbst, there are a growing number of rural organisations focusing on education, as well as social security and services. 39 per cent of organisations are active in the field of culture, and 15 per cent are active in the field of art. Activity can also be seen in the fields of local development, social services and social policies (25 per cent and 9 per cent respectively) (2018, p. 198). A larger number of entities 
are interested in satisfying social needs and resolving social issues of residents of rural municipalities. This increases their chances of formal and informal cooperation with local governments.

Thus if cooperation between various local entities is so important for effective implementation of local social policy, and if the number of those interested in working on behalf of local residents is increasing, the question of how its level can be diagnosed arises. In source literature we find no tools which would allow us to empirically express theoretical considerations, to compare various territorial entities in this respect, and determine, based on a listing with other variables, the conditions necessary for effective cooperation in the scope of co-creation and co-production social services in rural municipalities. The aim of this article is to validate such a tool.

\section{Methodology}

\subsection{Participants}

Local entities responsible for social policy in rural municipalities include gmina offices and municipal social welfare centres, non-governmental organisations involved in social policy, as well as social economy entities, of which few can be found in rural municipalities (Necel and Nosal 2016, p. 135).

Studies were conducted on a representative sample of public institutions responsible for satisfying social needs and resolving social issues. These included municipal (gmina) offices and municipal social welfare centres. From each randomly selected rural municipality one institution, i.e. municipal office (an organisational unit of a municipality, which helps the mayor (wójt) in the execution of the municipality's tasks and in resolutions of the local council) was invited to take part in the study. If the municipal office did not indicate a person to take part in the study, the invitation was sent to the municipal social welfare centre. The research tool, in the form of an on-line questionnaire, was filled out by the directors of social welfare centres (or delegated employees with the most in-depth knowledge of the functioning of the centres). If the participant was a municipal office the questionnaire was filled out by the person most involved in resolving local social issues (usually the municipal secretary or an employee of a section responsible for the implementation of social projects).

The study was conducted on a sample of 314 randomly selected rural municipalities, out of a total number of 1571 such units in Poland. The size of a representative sample with an assume fraction (of 0.5 ), was therefore estimated at no less than 310 . Each rural municipality was represented by one public institution 
responsible for resolving its residents' problems - a municipal social welfare centre or a municipal office.

\subsection{Instrument and Procedure}

The object of interest was cooperation, i.e. co-construction and co-production of social services (both formal and informal). The proposed research tool was subjected to cross validation, i.e. a division of the set into two parts. The first was used to assess the psychometric properties of the test's items. The second was used to determine its factor structure. There was an equal number of parts distinguished, i.e. 157 observations in each set, and the division was conducted by randomization.

The entire pool of generated items of the scale of such cooperation was comprised of 15 items. It was subjected to linguistic assessment of grammar and content. In accordance with the Ladder of Citizen Participation by Sherry Arnstein (1969), ${ }^{5}$ it also included items which did not represent cooperation in the field of co-creation and co-production of social services. As was noted, cooperation is preceded by searching for entities with which to engage, and by mutual information as to the activity conducted. The inclusion of such items was deemed necessary.

The scale was equipped with an instruction informing that the object of the study was the formal and informal cooperation of a given institution with NGOs and residents in the field of work on behalf of local residents, ${ }^{6}$ as well as the creation and production of social services. It was assumed that cooperation in the cocreation and co-production of social services is undertaken with entities that work to satisfy the needs of residents of municipalities. It is also a more "detailed" form of cooperation on behalf of residents of municipalities. Any cooperation on their behalf may constitute an impulse to undertake it in the area of social services addressed to residents of a given territorial unit.

In order to respond to the questions the authors used a two-point rating scale. The first position was ascribed the "yes" category and the second to the "no" category. The initial item pool used in the validation study is presented in Table 1.

In the analysis of data the authors used internal consistency of test and exploratory factor analysis, conducted using the principal component method, with factor rotation using the Oblimin method. Statistical inference was at a significance level of $\alpha=0.05$.

5 The Ladder of Citizen Participation is initiated by two items, which the author characterises as "non-participation", i.e. manipulation, and therapy.

6 This means activities aimed at satisfying the social needs of local residents and at resolving their social issues. 
Table 1. Initial item pool

\begin{tabular}{|c|c|}
\hline No. of item & Content \\
\hline 1 & $\begin{array}{l}\text { Does the institution know of other local entities (organisations, institutions) working } \\
\text { on behalf of local residents? }\end{array}$ \\
\hline 2 & $\begin{array}{l}\text { Do the aims of the institution include establishing contact with other local entities } \\
\text { in order to acquire and exchange information on their methods of working on behalf } \\
\text { of local residents? }\end{array}$ \\
\hline 3 & $\begin{array}{l}\text { Do the aims of the institution include establishing relations with other local entities } \\
\text { in order to co-create and co-produce social services offered to local residents? }\end{array}$ \\
\hline 4 & $\begin{array}{l}\text { Has the institution ever undertaken action in order to establish contact with other } \\
\text { local entities in order to exchange information on methods of working on behalf } \\
\text { of local residents? }\end{array}$ \\
\hline 5 & $\begin{array}{l}\text { Has the institution ever undertaken action in order to establish actual cooperation } \\
\text { with other local entities in order to co-create and co-produce social services? }\end{array}$ \\
\hline 6 & $\begin{array}{l}\text { Has the institution ever undertaken action in order to actually include local residents } \\
\text { in the process of planning activities to be conducted on their behalf? }\end{array}$ \\
\hline 7 & $\begin{array}{l}\text { Does the institution currently maintain contact with other local entities in order } \\
\text { to acquire and exchange information on methods of working on behalf of local } \\
\text { residents? }\end{array}$ \\
\hline 8 & $\begin{array}{l}\text { Does the institution cooperate with other organisations in the co-creation and co- } \\
\text { production of social services offered to local residents? }\end{array}$ \\
\hline 9 & $\begin{array}{l}\text { Does the institution usually include local residents in activities performed on their } \\
\text { behalf? }\end{array}$ \\
\hline 10 & $\begin{array}{l}\text { Does the institution conduct up-to-date assessment of its cooperation with other } \\
\text { local entities (with respect to its quality and effectiveness)? }\end{array}$ \\
\hline 11 & $\begin{array}{l}\text { Is the institution planning to establish contact with other local entities with which it } \\
\text { does not maintain contact, in the near future? }\end{array}$ \\
\hline 12 & $\begin{array}{l}\text { Does the institution conduct an up-to-date assessment of its activity in the scope } \\
\text { of including local residents in actions performed on their behalf? }\end{array}$ \\
\hline 13 & $\begin{array}{l}\text { Is the institution planning to undertake activities hitherto not conducted in order to } \\
\text { include local residents in actions performed on their behalf in the near future? }\end{array}$ \\
\hline 14 & $\begin{array}{l}\text { Does the institution provide access to its models of cooperation with other local } \\
\text { organisations and institutions and share them with other entities? }\end{array}$ \\
\hline 15 & $\begin{array}{l}\text { Does the institution provide access to its models concerned with including local } \\
\text { residents in activities conducted on their behalf and share them with other entities? }\end{array}$ \\
\hline
\end{tabular}

Source: Authors' own compilation.

\section{Results}

First the psychometric properties of individual test items were analysed. Then exploratory factor analysis was performed on a separate set of data in order to reveal 
superordinate variables, which would include individual test items. This approach allows us to reduce the number of variables to more general dimensions, thus revealing the test structure. In a separate step the authors assessed the consistency of the test and its scales distinguished through factor analysis.

\subsection{Analysis of Discriminating Power and Internal Consistency}

Assessment of the test's properties began with an approximation of item properties (Table 2). Attention was drawn to the correlation between the items and the test.

Table 2. Properties of the initial item pool

\begin{tabular}{ccc}
\hline Item No. & Coefficient of difficulty (approval) & Coefficient of discriminating power \\
\hline 1 & 0.92 & 0.37 \\
2 & 0.85 & 0.44 \\
3 & 0.83 & 0.41 \\
4 & 0.88 & 0.46 \\
5 & 0.76 & 0.58 \\
6 & 0.71 & 0.60 \\
7 & 0.85 & 0.57 \\
8 & 0.75 & 0.56 \\
9 & 0.79 & 0.59 \\
10 & 0.54 & 0.62 \\
11 & 0.27 & 0.29 \\
12 & 0.48 & 0.55 \\
13 & 0.29 & 0.33 \\
14 & 0.32 & 0.60 \\
15 & 0.28 & 0.58 \\
\hline
\end{tabular}

Source: Authors' own research.

The value of coefficients of discriminating power was satisfactory in the case of most items, with the exception of items 11 and 13. The value of Cronbach's alpha correlation coefficient is the measure of the test's internal consistency. For the scale consisting of 15 items Cronbach's alpha equalled 0.86. Agreeing and disagreeing in response to test items was clearly varied, as can be seen in the values of the coefficients of difficulty (approval). Its size is in the range of $0-1$. The closer 
it is to 1 , the more it indicates a generalised selection of high values on a rating scale in the case of items to which the coefficient refers. Its average size for the set of data gathered was moderate $(\mathrm{m}=0.66, \mathrm{sd}=0.24)$.

\subsection{Test Structure and Internal Consistency of Distinguished Scales}

In the case of the initial pool of test items, using factor analysis in order to reduce the number of variables was justified, as indicated by a sufficiently high value of the Kaiser-Meyer-Olkin coefficient $(\mathrm{KMO}=0.773)$, and by a statistically significant result in Bartlett's test of sphericity $\left(\mathrm{chi}^{2}=825.20, \mathrm{df}=105, \mathrm{p}=0.000\right)$, which indicates that correlations within the matrix of results were clearly higher than zero. Cattell's scree test indicated the presence of three factors, while at the same time fulfilling Kaiser's criterion, according to which the eigenvalue should be $\geq 1$. The eigenvalue of the first, second and third factor equalled 4.69, 1.81 and 1.33 respectively.

The value of the MSA (measure of sampling adequacy) coefficients, which constitute a measure of adequacy of individual variable selection (test items), reached a satisfactory level for each test item, i.e. values above 0.5 . Their average value was $0.78(\mathrm{sd}=0.06, \min =0.69, \max =0.89)$. This means that partial correlations for selected test items are adequately high. The results obtained justified conducting factor analysis. Because of the assumption that superordinate variables may correlate with each other the authors applied the Oblimin method in factor rotation, which is used for oblique factors. The results of factor analysis are presented in Table 3.

Table 3. Results of exploratory factor analysis using the main component method with Oblimin rotation

\begin{tabular}{cccc}
\hline Item & Factor $\mathbf{1}$ & Factor $\mathbf{2}$ & Factor 3 \\
\hline 1 & $\mathbf{0 . 5 7 7}$ & 0.083 & 0.142 \\
2 & $\mathbf{0 . 6 2 6}$ & 0.086 & 0.380 \\
3 & $\mathbf{0 . 7 1 1}$ & 0.109 & 0.286 \\
4 & $\mathbf{0 . 6 2 8}$ & -0.089 & -0.177 \\
5 & $\mathbf{0 . 6 4 1}$ & -0.035 & 0.110 \\
6 & 0.154 & -0.164 & $\mathbf{0 . 7 5 4}$ \\
7 & $\mathbf{0 . 7 0 5}$ & -0.178 & -0.346 \\
8 & $\mathbf{0 . 4 3 8}$ & -0.199 & -0.020 \\
9 & 0.091 & -0.125 & $\mathbf{0 . 7 4 5}$ \\
\hline
\end{tabular}


Table 3 - continued

\begin{tabular}{cccc}
\hline Item & Factor 1 & Factor 2 & Factor 3 \\
\hline 10 & 0.314 & -0.550 & -0.027 \\
11 & 0.053 & -0.512 & -0.083 \\
12 & 0.187 & -0.658 & 0.051 \\
13 & -0.137 & -0.558 & 0.302 \\
14 & -0.077 & -0.862 & -0.010 \\
15 & -0.041 & -0.826 & 0.079 \\
$\% S^{2}$ & 31.27 & 12.08 & 8.90 \\
\hline
\end{tabular}

$\% \mathrm{~S}^{2}$ - percentage of explained variance.

Source: Authors' own research.

The first factor was comprised of seven items, the second of six and the third of two. Factor loadings for particular test items are in the range of $-0.86-0.75$, while their absolute average value was 0.68 , which indicates a definite relationship between test items and superordinate variables distinguished in the course of analysis. The range of variance of measurement results explained by the test is slightly over $52 \%$ and is satisfactory. Correlations between factors are rather low, however, and they justify the use of oblique rotation (Table 4).

Table 4. Component correlation matrix

\begin{tabular}{crrr}
\hline Component & $\mathbf{1}$ & $\mathbf{2}$ & $\mathbf{3}$ \\
\hline 1 & & & \\
2 & -0.318 & & \\
3 & 0.184 & -0.129 & \\
\hline
\end{tabular}

Source: Authors' own research.

The internal consistency of particular scales was assessed using Cronbach's alpha correlation coefficients. The value of the coefficient equalled 0.76 for the first scale, 0.79 for the second and 0.72 for the third.

The results obtained increase the credibility of grouping test items within the framework of the factors distinguished, and present the tri-factor structure as well describing the data gathered. The factors distinguished were titled as follows: factor 1 - seeking entities for cooperation and working with them, factor 2 - including local residents in actions on their behalf, factor 3 - assessment of cooperation and working towards future cooperation. 


\section{Conclusions}

The effective implementation of social policy (in accordance with contemporary theory) requires cooperation between public institutions (legally obliged to implement it) and other entities, such as those representing the social sector. The need for their cooperation has been highlighted in the Strategy for Responsible Development. In rural municipalities the municipal offices and municipal social welfare centres can cooperate with NGOs (which act to satisfy residents' social needs) and with the residents themselves. It is undoubtedly a difficult task, especially in a post-socialist society, in which the potential for cooperation between citizens is generally low. Undertaking tasks in order to increase the potential for inter-sectoral cooperation as part of implementing social policy requires diagnosis. This generates the need for a tool that would allow us to determine the level of such cooperation (both formal and informal). The validation of such a tool was the aim of this article.

In the construction of this tool (the cooperation scale) the authors referred to the new public governance concept (reducing cooperation between public institutions, NGOs and residents in social policy to formal and informal co-creation and co-production of social services to satisfy the needs of residents of rural areas). Cooperation was separated from the-forms of inter-sectoral communication such as providing information on one's activities. The term "consultations" was also absent during item selection, as in the case of public institutions it is clearly associated with a form of public dialogue whose realisation is regulated by the Local Government Act of 8 March 1990.

The scale of inter-sectoral cooperation in implementing social policy is a trifactor construct, which means that its level is determined firstly by public institutions' search for entities to cooperate and to work with, secondly by the inclusion of local residents in actions taken on their behalf, and thirdly by its evaluation and actions taken in order to establish future cooperation. This allows us to determine the level of formal and informal inter-sectoral cooperation in rural municipalities as part of social policy, and thus for our analyses to consider the informal dimension of contacts between representatives of various sectors (so important to rural communities), which cannot be analysed using existing data such as official documents.

\section{Bibliography}

Arnstein S. (1969). A ladder of citizen participation. Journal of the American Planning Association, 35 (4), 216-224.

Dean R.J. (2018). Counter-governance: Citizen participation beyond collaboration. Politics and Governance, 6 (1), 180-188. 
Furmankiewicz M., Macken-Walsh A. (2016). Government within governance? Polish rural development partnerships through the lens of functional representation. Journal of Rural Studies, 46, 12-22.

Grewiński M., Karwacki A., Rymsza M. (2010). Nowa polityka społeczna: Aktywizacja, wielosektorowość, współdecydowanie. Warsaw: Mazowieckie Centrum Polityki Społecznej.

Halamska M., Maurel M.-C. (eds.) (2010). Les acteurs locaux á l’épreuve du modèle europeén LEADER. Praques-Varsovie: CEFRES, IRWiR PAN.

Halamska M., Śpiewak R., Michalska S. (2010). LEADER w Polsce: Drogi implementacji programu. Wieś i Rolnictwo, 4 (149), 104-119.

Hartley J. (2005). Innovation in governance and public services: Past and present. Public Money and Management, 25 (1), 27-34.

Herbst J. (2018). Nieocenione, niedocenione: Skala działań organizacji społecznych na wsi. In: J. Wilkin, I. Nurzyńska (eds.), Polska wieś 2018: Raport o stanie wsi (pp. 181-203). Warsaw: Scholar Publishing.

Journal of Laws 2003.0873. Ustawa z dnia 24 kwietnia 2003 r. o działalności pożytku publicznego i o wolontariacie (tekst jedn. Dz. U. z 2018 r., poz. 450).

Journal of Laws 1990.0095. Ustawa z dnia 8 marca 1990 r. o samorządzie gminnym (tekst jedn. Dz. U. z 2018 r., poz. 994).

Karolewski I. (2016). Protest and participation in post-transformation Poland: The case of the Committee for the Defense of Democracy (KOD). Communist and Post-communist Studies, 49, 255-267.

Leś E. (2013). Organizacje non profit w nowej polityce społecznej w Polsce na tle europejskim. Warsaw: Oficyna Wydawnicza Aspra - JR.

Marchaj R. (2016). Samorządowe konsultacje społeczne. Warsaw: Wolters Kluwer.

McLaughlin K., Ferlie E., Osborne S. (2001). New Public Management: Current Trends and Future Prospects. London: Routledge.

MIiR (Ministerstwo Inwestycji i Rozwoju) (2017). Strategia na rzecz Odpowiedzialnego Rozwoju do roku 2020 (z perspektywa do 2030 r.). Warsaw: Ministerstwo Inwestycji i Rozwoju.

Necel R., Nosal P. (2016). Samorząd województwa a lokalne podmioty polityki społecznej: Wzajemne relacje i ich uwarunkowania. Acta Universitatis Lodziensis. Folia Sociologica, $57,131-149$.

Pawłowska A., Gąsior-Niemiec A., Kołomycew A. (2014). Partnerstwa międzysektorowe na obszarach wiejskich: studium przypadku lokalnych grup działania w województwie podkarpackim. Warsaw: Scholar Publishing.

Pestoff V. (2012). Co-production and third sector social services in Europe: Some concepts and evidence. Voluntas. International Journal of Voluntary and Non-profit Organizations, 23, 1102-1118.

Pestoff V., Brandsen T., Verschuere B. (eds.). (2012). New Public Governance, the Third Sector and Co-production. London: Routledge.

Radnor Z., Osborne S.P. (2013). Lean: A failed theory for public services? Public Management Review, 15 (2), 265-287. 
Richardson L., Durose C., Perry B. (2018). Coproducing urban governance. Politics and Governance, 6 (1), 145-149.

Sidor M. (2017). Zlecanie zadań publicznych organizacjom pozarządowym - doświadczenia największych polskich miast. In: B. Dolnicki (ed.), Sposoby realizacji zadań publicznych (pp. 599-612). Warsaw: Wolters Kluwer.

Sześciło D. (2015). Samoobsługowe państwo dobrobytu: Czy obywatelska koprodukcja uratuje ustugi publiczne? Warsaw: Scholar Publishing.

Świdyński J., Świdyńska N. (2016). Konsultacje społeczne jako narzędzie współpracy obywateli z samorządem gminnym na przykładzie Olsztyna. Prace Naukowe Uniwersytetu Ekonomicznego we Wrocławiu, 443, 245-267.

Zacharko L. (2017). Innowacyjne rozwiązania w zakresie realizacji zadań publicznych gminy w Polsce i we Francji - modele kontaktowania usług społecznych. In: B. Dolnicki (ed.), Sposoby realizacji zadań publicznych (pp. 768-778). Warsaw: Wolters Kluwer.

Zajda K. (2018). Konsultacje społeczne a proces wdrażania innowacji społecznej. Samorzad Terytorialny, 7-8, 98-108.

Zajda K., Pasikowski S. (2018). Traits of leaders of rural non-governmental organisations as predictors of collaboration between NGOs and rural gmina offices: Voices from Central Poland. Voluntas. International Journal of Voluntary and Non-profit Organizations, June 2018, 1-14. https://doi.org/10.1007/s11266-018-9999-5 [accessed: 15.08. 2018].

\section{Skala międzysektorowej współpracy na rzecz realizacji polityki społecznej na wsi. Propozycja narzędzia badawczego}

Streszczenie: Współpraca lokalnych instytucji publicznych z organizacjami pozarządowymi i obywatelami ma zwiększać szanse na efektywną realizację polityki społecznej, rozumianej jako zespół działań na rzecz zaspokajania społecznych potrzeb i rozwiązywania problemów społecznych. Celem artykułu jest zaprezentowanie narzędzia, które pozwoli określić poziom współpracy między tymi podmiotami w zakresie tworzenia (co-creation) i realizacji (co-production) usług społecznych zaspokajających potrzeby mieszkańców gmin wiejskich. Omówione zostaną wyniki analiz przeprowadzonych w 2018 r. na reprezentatywnej dla gmin wiejskich próbie instytucji publicznych zajmujących się odpowiadaniem na potrzeby społeczne mieszkańców wsi, w tym rozwiązywaniem dotykających ich problemów społecznych. W ich świetle skala jest konstruktem trójczynnikowym, który uwzględnia takie czynniki, jak: 1. poszukiwanie podmiotów do współpracy i działanie z nimi, 2. włączanie mieszkańców gminy w działania na ich rzecz, 3. ewaluacja współpracy i podejmowanie działań na rzecz jej podejmowania w przyszłości.

Słowa kluczowe: lokalna polityka społeczna, współpraca podmiotów lokalnej polityki społecznej, gminy wiejskie. 